\title{
Evaluation of Using Satellite-Derived Aerosol Optical Depth in Land Use Regression Models for Fine Particulate Matter and Its Elemental Composition
}

\author{
Chun-Sheng Huang ${ }^{1}$, Ho-Tang Liao ${ }^{1}{ }^{\mathbb{D}}$, Tang-Huang Lin ${ }^{2}{ }^{\mathbb{D}}$, Jung-Chi Chang ${ }^{1}$, Chien-Lin Lee ${ }^{1}$, \\ Eric Cheuk-Wai Yip ${ }^{1}$, Yee-Lin $\mathrm{Wu}^{3}$ and Chang-Fu Wu ${ }^{1,4, *}$
}

1 Institute of Environmental and Occupational Health Sciences, National Taiwan University, Room 717, No.17, Xu-Zhou Road, Taipei 100, Taiwan; d08852003@ntu.edu.tw (C.-S.H.); arisliao@gmail.com (H.-T.L.); R04844013@ntu.edu.tw (J.-C.C.); skyconcerto10@gmail.com (C.-L.L.); r08852035@ntu.edu.tw (E.C.-W.Y.)

2 Center for Space and Remote Sensing Research, National Central University, Taoyuan 320, Taiwan; thlin@csrsr.ncu.edu.tw

3 Department of Environmental Engineering, National Cheng Kung University, Tainan 701, Taiwan; ylwu@mail.ncku.edu.tw

4 Department of Public Health, National Taiwan University, Taipei 100, Taiwan

* Correspondence: changfu@ntu.edu.tw; Tel./Fax: +886-2-3366-8096

check for updates

Citation: Huang, C.-S.; Liao, H.-T.; Lin, T.-H.; Chang, J.-C.; Lee, C.-L.; Yip, E.C.-W.; Wu, Y.-L.; Wu, C.-F. Evaluation of Using Satellite-Derived Aerosol Optical Depth in Land Use Regression Models for Fine Particulate Matter and Its Elemental Composition. Atmosphere 2021, 12, 1018. https://doi.org/10.3390/ atmos12081018

Academic Editors: Chris G. Tzanis, Artur Badyda and

Theodoros Christoudias

Received: 2 July 2021

Accepted: 5 August 2021

Published: 8 August 2021

Publisher's Note: MDPI stays neutral with regard to jurisdictional claims in published maps and institutional affiliations.

Copyright: (c) 2021 by the authors. Licensee MDPI, Basel, Switzerland. This article is an open access article distributed under the terms and conditions of the Creative Commons Attribution (CC BY) license (https:// creativecommons.org/licenses/by/ $4.0 /)$.

\begin{abstract}
This study introduced satellite-derived aerosol optical depth (AOD) in land use regression (LUR) modeling to predict ambient concentrations of fine particulate matter $\left(\mathrm{PM}_{2.5}\right)$ and its elemental composition. Twenty-four daily samples were collected from 17 air quality monitoring sites $(\mathrm{N}=408)$ in Taiwan in 2014. A total of 12 annual LUR models were developed for $\mathrm{PM}_{2.5}$ and 11 elements, including aluminum, calcium, chromium, iron, potassium, manganese, sulfur, silicon, titanium, vanadium, and zinc. After applied AOD and a derived-predictor, AOD percentage, in modeling, the number of models with leave-one-out cross-validation $R^{2}>0.40$ significantly increased from 5 to 9 , indicating the substantial benefits for the construction of spatial prediction models. Sensitivity analyses of using data stratified by $\mathrm{PM}_{2.5}$ concentrations revealed that the model performances were further improved in the high pollution season.
\end{abstract}

Keywords: air pollution; elemental composition; land use regression; aerosol optical depth

\section{Introduction}

Many epidemiological studies have revealed that exposure to particulate matter with an aerodynamic diameter less than $2.5 \mu \mathrm{m}\left(\mathrm{PM}_{2.5}\right)$ is associated with adverse health effects [1-4]. In recent years, an increasing number of studies focused on source-specific $\mathrm{PM}_{2.5}$ and associated composition because they may affect human health more specifically [5-9]. For example, wood combustion, which is mainly characterized by potassium (K), was found having a strong association with mortality [8].

To predict the exposure to air pollutants, land use regression (LUR) models were developed based on air pollutants acquired at numerous locations and surrounding land use information extracted using geographic information system (GIS) as predictor variables $[10,11]$. On the basis of variables selected in the final models, critical sources of air pollutants can be identified [12-15].

The LUR model has been employed to predict the spatial distribution of $\mathrm{PM}_{2.5}$-bound elemental composition in previous studies [16-23]. However, most of these studies were conducted in the United States, Europe, and Australia. Because culture-specific sources (e.g., burning of joss sticks and papers in Chinese temples) may contribute to $\mathrm{PM}_{2.5}$ composition, developing the LUR model to study $\mathrm{PM}_{2.5}$ composition sources in Asia is crucial. Hsu et al. [17] developed LUR models using the satellite-derived data of vegetation index for $\mathrm{PM}_{2.5}$ composition based on repeated measurements at six monitoring sites in Taiwan. 
The composition with good model performance $\left(R^{2} \geq 0.50\right)$ include ammonium $\left(\mathrm{NH}_{4}{ }^{+}\right)$, sulfate $\left(\mathrm{SO}_{4}{ }^{2-}\right)$, nitrate $\left(\mathrm{NO}_{3}{ }^{-}\right)$, organic carbon $(\mathrm{OC})$, elemental carbon (EC), barium (Ba), manganese $(\mathrm{Mn})$, copper $(\mathrm{Cu})$, zinc $(\mathrm{Zn})$, and antimony $(\mathrm{Sb})$. Nevertheless, the limited number of monitoring sites might restrict its applicability to predict the spatial variation of $\mathrm{PM}_{2.5}$ composition in a wide area. Furthermore, the utility of other satellite data (e.g., aerosol optical depth, AOD) was not explored in Hsu et al.'s study. In general, land use information indicates the surface emission solely while the satellite AOD includes the transport part of pollutants.

In this technical note, LUR models were constructed for $\mathrm{PM}_{2.5}$, aluminum (Al), calcium $(\mathrm{Ca})$, chromium $(\mathrm{Cr})$, iron $(\mathrm{Fe})$, potassium $(\mathrm{K}), \mathrm{Mn}$, sulfur $(\mathrm{S})$, silicon $(\mathrm{Si})$, titanium $(\mathrm{Ti})$, vanadium $(\mathrm{V})$, and $\mathrm{Zn}$ composition based on 17 monitoring sites in Taiwan. The efficacy of utilizing satellite-derived AOD was also evaluated.

\section{Material and Methods}

\section{1. $P M_{2.5}$ Sample Collection and Chemical Analysis}

Filter-based $\mathrm{PM}_{2.5}$ samples used in this study were collected in Taiwan, which has an approximate population of 23 million and an area of $36,000 \mathrm{~km}^{2}$. Here, 24 daily samples (two samples per month per site in 2014) from 17 air quality monitoring sites, total 408 samples, were obtained from Taiwan Environmental Protection Administration (TEPA) (www.epa.gov.tw) and applied for chemical analysis. Figure 1 shows the locations of sites.

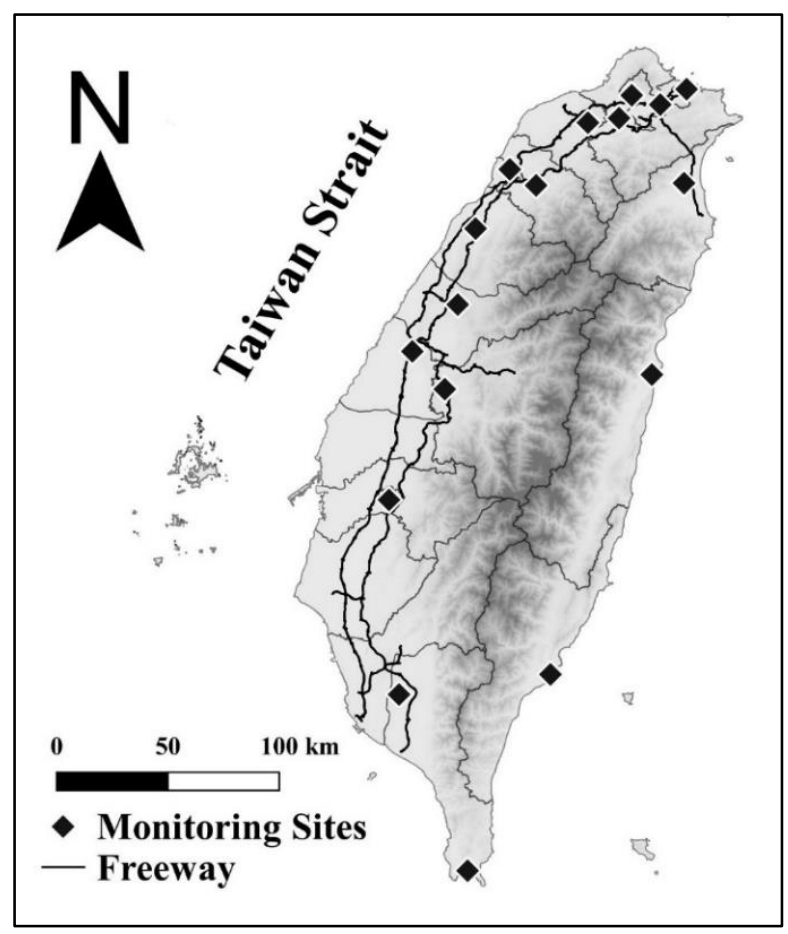

Figure 1. Locations of 17 selected TEPA monitoring sites including in this study.

A total of 11 elemental composition, including $\mathrm{Al}, \mathrm{Ca}, \mathrm{Cr}, \mathrm{Fe}, \mathrm{K}, \mathrm{Mn}, \mathrm{S}, \mathrm{Si}, \mathrm{Ti}, \mathrm{V}$, and $\mathrm{Zn}$, were quantitatively obtained using energy-dispersive $\mathrm{X}$-ray fluorescence spectrometry with a high detection rate $(\geq 70 \%)$ [15]. Calibration curves were built using thin-film standards (Micromatter, Vancouver, Canada). National Institute of Standards and Technology standard reference material (SRM 2783) was used to verify the measurements (Table S1). Furthermore, the method detection limit was computed as triple the standard deviation of the detected signals of each element in 10 blank Teflon filters. A multi-elemental quality control standard (Micromatter, Vancouver, BC, Canada) was analyzed for each batch of samples to ensure instrument performance. 


\subsection{Collection of LUR Predictors}

For developing models, this study collected diverse potential predictors, including land use, road information, elevation, demographic data, location of stationary emission sources (e.g., factories and boilers), temples, and satellite data. A total of 21 predictor variables were created: area of road, residence, industry, port, semi-natural, and forest and urban green; length of road and distance to road; number of population, household, emission sources, and temples; extracted AOD values. The predictor variables are similar to the ones in our previous study and can be found elsewhere [24]. For detailed information of predictors, please see Table S2 of Supplementary Materials. The predictor variables applied in this study were processed and extracted using Quantum GIS 2.8.9 (QGIS) [25].

In this study, satellite-derived predictor of AOD was introduced in LUR model constructions to assess the efficacy for estimating concentrations of $\mathrm{PM}_{2.5}$ and the elemental composition. Larger AOD values indicate a hazier condition and higher aerosol concentration in atmosphere. The daily AOD acquired in this study were measured by moderate resolution imaging spectroradiometers (MODIS) onboard Terra and Aqua satellites via the principle of optical properties of aerosol (e.g., extinction or backscatter). AOD in spatial resolution of $3 \mathrm{~km} \times 3 \mathrm{~km}$ were retrieved from MODIS aerosol products of MOD04_3K and MYD04_3K. Average AOD were computed from the $3 \times 3$ group (i.e., a $9 \mathrm{~km} \times 9 \mathrm{~km}$ area centered at each air quality monitoring site) to reduce the effects of having missing $A O D$ value at the center pixel. To further utilize the AOD data, an additional predictor, the AOD percentage (AOD_PER), was calculated based on the following formula:

$$
\text { Daily AOD_PER }=\frac{\text { number of pixels with available AOD }}{9 \text { (total number of pixels })}
$$

Daily AOD is calculated as an average of Terra and Aqua AOD values. Annual averages of AOD and AOD_PER were computed based on 365 daily values for modeling.

\subsection{Model Constructions}

LUR is built with a supervised stepwise selection procedure [12] using SAS statistical software (SAS 9.4; SAS Institute Inc., Cary, NC, USA). The construction procedure is described concisely as follows. Firstly, the start model was chosen as the univariate linear regression model with the highest adjusted explained variance (adjusted $R^{2}$ ). Next, remaining predictors were sequentially regressed against the start model and the predictor was retained if the criteria were all achieved: (a) has the highest improved adjusted $R^{2}$ (also > 0.01), (b) direction of coefficient matched with the anticipated effect, and (c) directions of remaining predictors were unchanged. Then, the predictors with $p$-value higher than 0.10 were removed after no more predictors met the above criteria. For predictors with variance inflation factor (VIF) $>3$, the one with the highest VIF value was excluded to minimize the collinearity effects. Cook's D and Moran's I were utilized for evaluating influential sites and spatial autocorrelations. LUR model performance was assessed by leave-one-out cross-validation (LOOCV) and root mean square error (RMSE).

In this study, three methods were assessed for annual LUR model constructions. For Method 1, non-satellite predictors, including land use, road information, elevation, demographic data, stationary emission sources, and temples were applied for model building. For Method 2, AOD was added to the aforementioned predictors in Method 1. For Method 3, AOD_PER was introduced to the former predictors in Method 2. In addition, two scenarios defined as "high $\mathrm{PM}_{2.5}$ season" (HPS) and "low $\mathrm{PM}_{2.5}$ season" (LPS), classified by the period with $\mathrm{PM}_{2.5}$ concentration higher or lower than the average value, were developed using Method 3 for sensitivity analysis.

\section{Results and Discussion}

\subsection{Summary Statistics of PM Measures}

Figure 2 and Table S3 show the concentration distributions of $\mathrm{PM}_{2.5}$ and elemental composition in annual, HPS and LPS averages. For $\mathrm{PM}_{2.5}$, the annual concentration 
was $21.0 \mu \mathrm{g} / \mathrm{m}^{3}$. Among the compositions, $\mathrm{S}$ showed the highest annual concentration $\left(3164.4 \mathrm{ng} / \mathrm{m}^{3}\right)$, followed by K $\left(448.5 \mathrm{ng} / \mathrm{m}^{3}\right)$ and $\mathrm{Si}\left(343.7 \mathrm{ng} / \mathrm{m}^{3}\right)$, whereas V exhibited the lowest value $\left(9.0 \mathrm{ng} / \mathrm{m}^{3}\right)$. Annual concentrations among other composition ranged from 11.5 to $191.9 \mathrm{ng} / \mathrm{m}^{3}$. The mean concentrations of PM measures are generally 1.0-1.5 times and 0.7-1.0 times as annual averages in HPS and LPS, respectively.

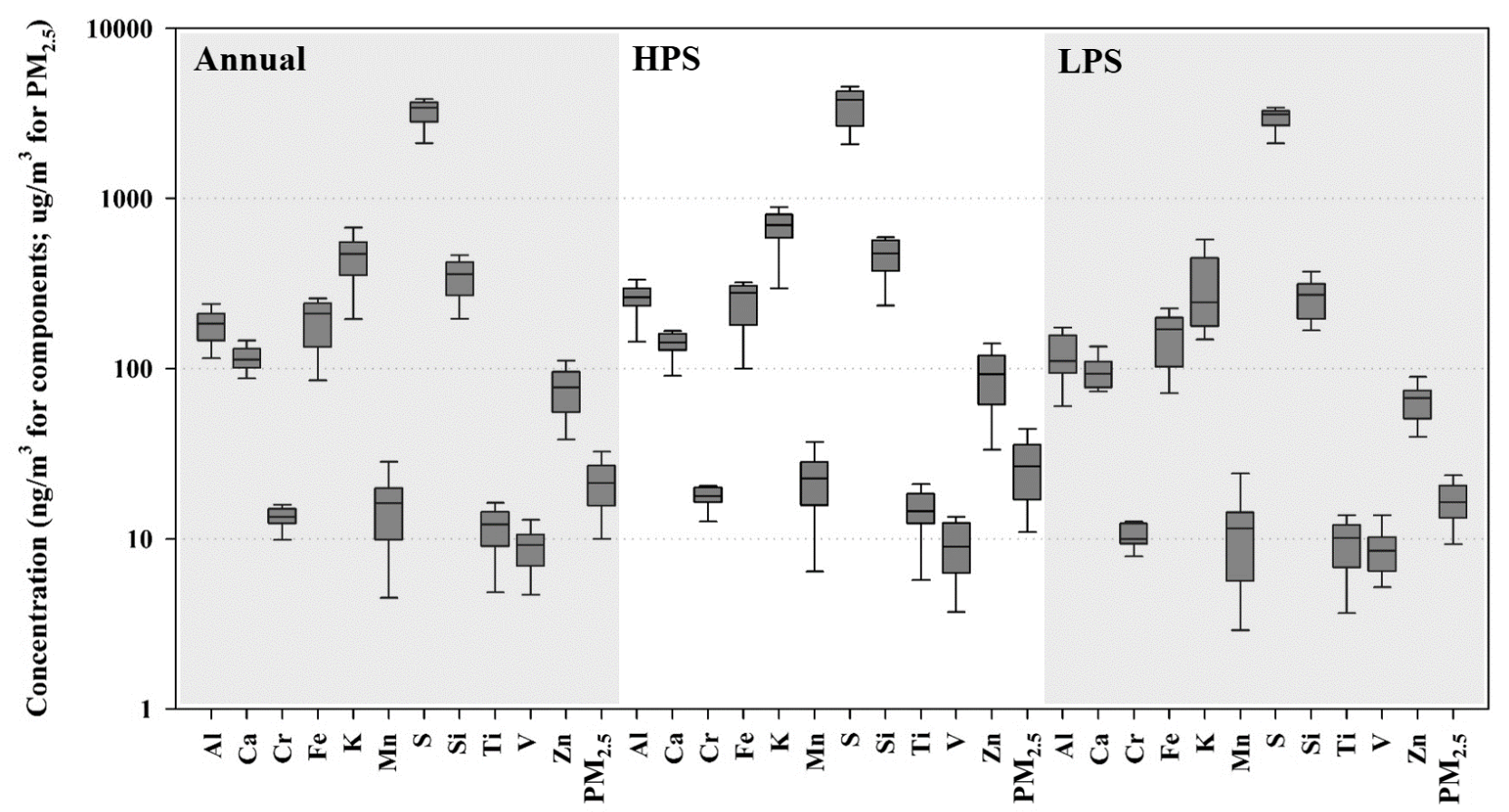

Figure 2. Concentration distributions of PM measures for annual value, high $\mathrm{PM}_{2.5}$ season (HPS) and low $\mathrm{PM}_{2.5}$ season (LPS) (the box represents 25th-75th percentiles and median, and the whiskers represent 10th and 90th percentiles) ( $\mathrm{N}=17)$.

\subsection{LUR Modeling Results}

Among the three methods for constructing annual LUR models, Method 3 (considering AOD and AOD_PER as predictors) showed the best overall performance (median LOOCV $R^{2}=0.70$ ) than Methods 1 and 2 (median LOOCV $R^{2}=0.37$ and 0.44 , respectively) (Table 1 ). Compared with the temporal-invariant land use predictors, satellite AOD and AOD_PER vary with time. Although their average values corresponding to the specific periods (i.e., annual, HPS, or LPS) were used in the models, they still are useful for representing the underlying variation of PM measures over time and space. Given the length restrictions of a technical note, we only discuss the main results of Method 3. For the summary of LUR models developed based on Methods 1 and 2, please refer to Tables S4 and S5 of Supplementary Materials.

Table 2 shows the annual model performances of $\mathrm{PM}_{2.5}$ and elemental composition from Method 3. LOOCV $R^{2}$ among $12 \mathrm{PM}$ measures ranged from 0.07 (V and $\mathrm{Cr}$ ) to $0.92(\mathrm{Si})$. Most PM measures, including $\mathrm{PM}_{2.5}, \mathrm{Ca}, \mathrm{Fe}, \mathrm{K}, \mathrm{Mn}, \mathrm{S}, \mathrm{Si}$, Ti, and $\mathrm{Zn}$, showed LOOCV R ${ }^{2}$ higher than 0.40 , indicating reasonable performance of the constructed LUR models. The length and surface area of road network and distance to road were applied in LUR development to represent traffic factors. $\mathrm{Ca}, \mathrm{Fe}, \mathrm{Si}, \mathrm{Ti}$, and $\mathrm{Zn}$ retained road-related predictors in the final models. $\mathrm{Ca}, \mathrm{Fe}, \mathrm{Si}$, and $\mathrm{Ti}$ are regarded as crustal elements and roadside dust, which may be re-suspended by wind flow and heavy traffic [26-28]. Fe and Zn may be contributed by the abrasion of tire wear or brake linings from automobiles [29-31]. 
Table 1. LOOCV $R^{2}$ and selected satellite-derived predictors among land use regression models based on different methods.

\begin{tabular}{|c|c|c|c|c|c|c|c|c|c|c|c|c|}
\hline \multirow{3}{*}{$\begin{array}{c}\text { PM } \\
\text { Measures }\end{array}$} & \multicolumn{6}{|c|}{ Annual Model: Evaluating AOD and AOD_PER Efficacy in LUR } & \multirow{2}{*}{\multicolumn{3}{|c|}{$\begin{array}{c}\text { Scenario 1: } \\
\text { High } \text { PM }_{2.5} \text { Season (HPS) } \\
\text { Method 3: } \\
\text { Base + AOD + AOD_PER }\end{array}$}} & \multirow{2}{*}{\multicolumn{3}{|c|}{$\begin{array}{c}\text { Scenario 2: } \\
\text { Low } \text { PM }_{2.5} \text { Season (LPS) } \\
\text { Method 3: } \\
\text { Base + AOD + AOD_PER }\end{array}$}} \\
\hline & \multirow{2}{*}{$\begin{array}{l}\begin{array}{c}\text { Method 1: } \\
\text { Base }\end{array} \\
\text { LOOCV } R^{2}\end{array}$} & \multicolumn{2}{|c|}{$\begin{array}{c}\text { Method 2: } \\
\text { Base + AOD }\end{array}$} & \multicolumn{3}{|c|}{$\begin{array}{c}\text { Method 3: } \\
\text { Base + AOD + AOD_PER }\end{array}$} & & & & & & \\
\hline & & LOOCV $R^{2}$ & AOD $^{a}$ & LOOCV $R^{2}$ & AOD & $\underset{a}{A O D \_P E R}$ & LOOCV $R^{2}$ & AOD & AOD_PER & LOOCV $R^{2}$ & AOD & AOD_PER \\
\hline $\mathrm{PM}_{2.5}$ & 0.35 & 0.44 & Y & 0.69 & $\mathrm{Y}$ & $\mathrm{Y}$ & 0.91 & $\mathrm{Y}$ & $\mathrm{Y}$ & 0.40 & $\mathrm{Y}$ & \\
\hline $\mathrm{Al}$ & 0.33 & 0.44 & $\mathrm{Y}$ & 0.26 & & & 0.70 & & $\mathrm{Y}$ & 0.55 & $\mathrm{Y}$ & \\
\hline $\mathrm{Cr}$ & 0.24 & 0.24 & & 0.07 & & $\mathrm{Y}$ & 0.62 & & $\mathrm{Y}$ & 0.29 & & $\mathrm{Y}$ \\
\hline $\mathrm{Fe}$ & 0.40 & 0.63 & $\mathrm{Y}$ & 0.77 & $\mathrm{Y}$ & $\mathrm{Y}$ & 0.80 & & $\mathrm{Y}$ & 0.43 & $\mathrm{Y}$ & \\
\hline K & 0.40 & 0.30 & $\mathrm{Y}$ & 0.71 & & $\mathrm{Y}$ & 0.67 & & $\mathrm{Y}$ & 0.33 & $\mathrm{Y}$ & \\
\hline Mn & 0.05 & 0.70 & $\mathrm{Y}$ & 0.69 & & $\mathrm{Y}$ & 0.90 & & Y & 0.80 & $\mathrm{Y}$ & \\
\hline$S$ & 0.34 & 0.40 & $\mathrm{Y}$ & 0.86 & $\mathrm{Y}$ & $\mathrm{Y}$ & 0.87 & & $\mathrm{Y}$ & 0.36 & $\mathrm{Y}$ & \\
\hline $\mathrm{Si}$ & 0.39 & 0.47 & $\mathrm{Y}$ & 0.92 & & $\mathrm{Y}$ & 0.49 & & Y & 0.76 & & $\mathrm{Y}$ \\
\hline $\mathrm{Ti}$ & 0.41 & 0.41 & & 0.80 & & $\mathrm{Y}$ & 0.86 & & $\mathrm{Y}$ & 0.49 & & $\mathrm{Y}$ \\
\hline $\mathrm{V}$ & 0.07 & 0.07 & & 0.07 & & & 0.53 & & $\mathrm{Y}$ & 0.07 & & \\
\hline $\mathrm{Zn}$ & 0.44 & 0.57 & Y & 0.83 & $\mathrm{Y}$ & $\mathrm{Y}$ & 0.91 & & $\mathrm{Y}$ & 0.71 & & $\mathrm{Y}$ \\
\hline Median & 0.37 & 0.44 & & 0.70 & & & 0.76 & & & 0.46 & & \\
\hline$>0.40^{\mathrm{b}}$ & 5 & 9 & & 9 & & & 12 & & & 8 & & \\
\hline
\end{tabular}

a Represents whether AOD or AOD_PER was retained in the final model. "Y" denotes Yes. ${ }^{\mathrm{b}}$ Represents the number of models higher than LOOCV $R^{2}$ of 0.40. 
Table 2. Summary of land use regression models of $\mathrm{PM}_{25}$ and elemental composition using annual averages (Method 3).

\begin{tabular}{|c|c|c|c|c|c|c|}
\hline PM Measures & LUR Model $^{\text {a }}$ & $R^{2}$ of Model & Adjusted $R^{2}$ & LOOCV $R^{2}$ & LOOCV RMSE $^{b}$ & $p$-Value of Moran's I \\
\hline $\mathrm{PM}_{2.5}$ & $\begin{array}{l}-1.05-542.39 \times \text { URBANGREEN_100 + } 0.03 \times \\
\text { POINT N } 5000+23.71 \times \text { AOD }+120.10 \times \text { AOD PER }\end{array}$ & 0.84 & 0.78 & 0.69 & 4.28 & 0.43 \\
\hline $\mathrm{Al}$ & $145.24+1061.16 \times$ URBANGREEN_500 & 0.40 & 0.36 & 0.26 & 39.93 & 0.57 \\
\hline $\mathrm{Ca}$ & $\begin{array}{c}76.97+457.55 \times \text { MAJORRAODAREA_500 + } 96.48 \times \\
\text { MAJORROADLEN_100 }\end{array}$ & 0.70 & 0.66 & 0.58 & 14.02 & 0.58 \\
\hline $\mathrm{Cr}$ & $\begin{array}{c}12.26+6.22 \times \text { INDUSTRY_1000 }-155.46 \times \\
\text { SEMINATURAL + } 16.86 \times \text { AOD_PER }\end{array}$ & 0.54 & 0.44 & 0.07 & 1.90 & 0.12 \\
\hline $\mathrm{Fe}$ & $\begin{array}{c}-30.58+1230.54 \times \text { MAJORROADAREA_500 }-5168.54 \\
\times \text { URBANGREEN_100 }+0.25 \times \text { POINT_N_5000 }+ \\
275.39 \times \text { AOD }+595.94 \times \text { AOD_PER } \\
78.31-8741.33 \times \text { URBANGREEN } 100+0.49 \times\end{array}$ & 0.87 & 0.81 & 0.77 & 32.44 & 0.46 \\
\hline $\mathrm{K}$ & $\begin{array}{c}\text { POINT_N_5000 }+0.66 \times \text { TEMPLE_5000 }+3511.40 \times \\
\text { AOD_PER }\end{array}$ & 0.88 & 0.85 & 0.71 & 81.01 & 0.16 \\
\hline Mn & $\begin{array}{c}2.36+54.86 \times \text { INDUSTRY_1000 + } 0.02 \times \\
\text { POINT_N_5000 + 106.78 } \times \text { AOD_PER } \\
1044.46-50105.99 \times \text { URBANGREEN_100 }+2.54 \times\end{array}$ & 0.84 & 0.80 & 0.69 & 5.07 & 0.77 \\
\hline S & $\begin{array}{c}\text { HOUSEHOLD_5000 }+162.53 \times \text { TEMPLE_300 + } 1585.70 \\
\times \text { AOD }+14110.58 \times \text { AOD_PER } \\
37.56+1406.59 \times \text { ALLROADAREA_300 }+37.15 \times\end{array}$ & 0.92 & 0.88 & 0.86 & 234.74 & 0.85 \\
\hline $\mathrm{Si}$ & $\begin{array}{c}\text { INDUSTRY_5000 }-11749.47 \times \text { URBANGREEN_100 + } \\
9661.14 \times \text { DISTINVMR }+14.00 \times \text { TEMPLE_300 + } \\
1977.17 \times \text { AOD_PER } \\
-0.88+6.50 \times \text { ALLROADAREA_1000 }-393.67 \times\end{array}$ & 0.97 & 0.96 & 0.92 & 29.29 & 0.77 \\
\hline $\mathrm{Ti}$ & $\begin{array}{c}\text { URBANGREEN_100 + } 0.01 \times \text { POINT_N_5000 }+0.03 \times \\
\text { TEMPLE_5000 }+69.08 \times \text { AOD_PER }\end{array}$ & 0.90 & 0.86 & 0.80 & 1.83 & 0.90 \\
\hline V & $\begin{array}{c}7.25+1.62 \times \text { TEMPLE_300 } \\
-3.72+2750.53 \times \text { ALLROADAREA_100 }+43.53 \times\end{array}$ & 0.35 & 0.31 & 0.07 & 3.28 & 0.80 \\
\hline $\mathrm{Zn}$ & $\begin{array}{l}\text { MAJORROADAREA_1000 + } 7.12 \times \text { INDUSTRY_5000 - } \\
2163.13 \times \text { URBANGREEN_100 + } 66.32 \times \text { AOD }+277.57 \\
\quad \times \text { AOD_PER }\end{array}$ & 0.92 & 0.88 & 0.83 & 10.48 & 0.76 \\
\hline
\end{tabular}

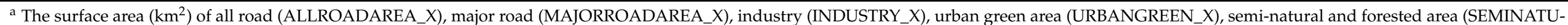

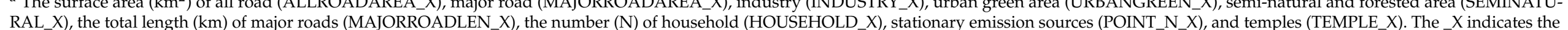

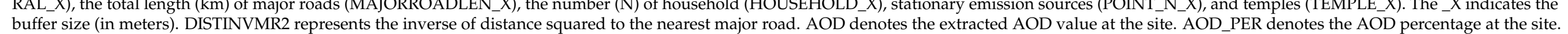

${ }^{b}$ The concentration of $\mathrm{PM}_{2.5}$ and elemental composition are represented as $\mu \mathrm{g} / \mathrm{m}^{3}$ and $\mathrm{ng} / \mathrm{m}^{3}$, respectively. 
INDUSTRY (industrial area in buffer size (i.e., radius) of 1000 or $5000 \mathrm{~m}$ ) and number of stationary emission sources (POINT_N_5000) were selected in the models of $\mathrm{PM}_{2.5}, \mathrm{Cr}, \mathrm{Fe}$, $\mathrm{K}, \mathrm{Mn}, \mathrm{Si}$, Ti, and $\mathrm{Zn}$. $\mathrm{Cr}, \mathrm{Fe}, \mathrm{K}, \mathrm{Mn}$, and $\mathrm{Zn}$ may be emitted from the ferrous or non-ferrous metal processing of industrial sources [32-34]. Si and Ti belong to crustal elements and are commonly utilized as markers of soil or construction dusts [35], and may also present in the industrial process of cement production or metal manufacturing $[33,36,37]$. Besides, the large buffer size $(5000 \mathrm{~m})$ implied that the elemental composition were influenced by distant industrial sources. Comparing with the studies conducted in Taipei and Kaohsiung in Taiwan, the industrial area variables were also retained in the final LUR models for $\mathrm{PM}_{2.5}, \mathrm{Fe}, \mathrm{Mn}, \mathrm{Si}$, Ti, and $\mathrm{Zn}[15,38]$.

In this study, the number of temples was considered as a culture-specific predictor in model constructions. Five composition, $\mathrm{K}, \mathrm{S}, \mathrm{Si}$, $\mathrm{Ti}$, and $\mathrm{V}$, retained the variable of temples in the final models. This variable was not significant in Hsu et al. [17], possibly because the limited number of monitoring sites in that study did not reflect the variabilities of environmental information. More geographically heterogeneous sites are expected to be included in LUR modeling for sufficiently representing the features of study areas.

Satellite-derived predictor of AOD was selected in four models among $12 \mathrm{PM}$ measures (Table 1), including $\mathrm{PM}_{2.5}, \mathrm{Fe}, \mathrm{S}$, and $\mathrm{Zn}$. AOD_PER was retained in nine models of $\mathrm{PM}_{2.5}$, $\mathrm{Cr}, \mathrm{Fe}, \mathrm{K}, \mathrm{Mn}, \mathrm{S}, \mathrm{Si}$, Ti, and $\mathrm{Zn}$. LOOCV $R^{2}$ of most PM measures increased significantly after AOD and AOD_PER were introduced in modeling, as compared to results from Method 1. For $\mathrm{PM}_{2.5}, \mathrm{Fe}, \mathrm{K}, \mathrm{Mn}, \mathrm{S}, \mathrm{Si}$, Ti, and $\mathrm{Zn}, \mathrm{LOOCV} \mathrm{R}^{2}$ increased more than 0.30 . AOD and AOD_PER exhibited a strong Pearson correlation with $\mathrm{PM}_{2.5}$ (0.75 with AOD; 0.69 with AOD_PER) and specific elemental composition (ranged from 0.69 to 0.72 with AOD; 0.35 to 0.74 with AOD_PER), and thus beneficial for the construction of spatial prediction model. AOD is obtained through measuring the extinction of the solar beam by particles, which relates to the amount of suspended aerosol in atmosphere. However, LOOCV $R^{2}$ of $\mathrm{Al}$ and $\mathrm{Cr}$ model decreased. Predictor selection procedures were examined, which indicated that the presence of AOD or AOD_PER affected the selection procedures and changed the results. Thus, the model did not always give superior performance as more predictors were considered in model constructions.

AOD_PER showed positive coefficients in all nine LUR models. The value of AOD_PER depends on the availability of AOD, which is mainly influenced by cloud cover effect. Higher AOD_PER indicates fewer missing values and therefore less cloud cover effects, leading to the lower possibilities of precipitation and higher potentials of photochemical reaction from solar radiation. Precipitation reduces $\mathrm{PM}_{2.5}$ concentration in the atmosphere and corresponds with the decrease of elemental composition in $\mathrm{PM}_{2.5}$ mixtures while the photochemical reaction partially contributes to the formation of secondary aerosol. Furthermore, the fine particulate matters with higher hygroscopicity potentially facilitate the cloud formation which is related to AOD_PER value, indicating that the AOD_PER parameter includes the information of aerosol type.

In this study, the samples were divided into HPS and LPS based on $\mathrm{PM}_{2.5}$ levels higher or lower than the average value $\left(=21.0 \mu \mathrm{g} / \mathrm{m}^{3}\right)$ and LUR models were built accordingly using Method 3 (Tables S6 and S7). January to April and December were classified as the HPS while May to November as the LPS. The average temperature during the HPS and LPS was 18.7 vs. $28.1^{\circ} \mathrm{C}$, respectively (Figure S1). During the cold season, the lower mixing height would be favorable to form high air pollutions [39]. Overall, the model performed better during the HPS than during the LPS (Table 1 , median LOOCV $R^{2}=0.76$ vs. 0.46 ). Additionally, AOD_PER showed higher occurrences in HPS models than in LPS models. AOD_PER represents an indirect indicator of cloud coverage, implying that meteorological factors might be decisive predictors and more critical to estimate the levels of $\mathrm{PM}_{2.5}$ and associated elemental composition during the HPS than the LPS. Moreover, $\mathrm{Al}, \mathrm{Ca}$, and $\mathrm{Mn}$ showed better LOOCV $R^{2}$ in both HPS and LPS models than in the annual models. This suggests that predictors might have different effects on certain PM measures by seasons, which cannot be reflected in annual models. For example, AOD_PER was retained in the 
HPS model but not annual model for Al. This may be because the meteorological variability was smoothed out in annual averages, thus cannot reflect the seasonal variance of Al level by AOD_PER.

For applications in epidemiological studies, most previous studies considered LOOCV $R^{2}$ greater than 0.40 as an inclusion criterion [40-43]. Table 1 shows that the number of applicable models (LOOCV $R^{2}>0.40$ ) was nine (Method 3) for the annual data, and increased to 12 for HPS. It was also noted that the LOOCV $R^{2}$ of $\mathrm{Al}, \mathrm{Cr}$, and $\mathrm{V}$ improved significantly from $<0.3$ in the annual models to $0.70,0.62$, and 0.53 , respectively, in HPS models. This suggests potential influence of diverse meteorological conditions between clean and hazy days. Further investigation is needed to explore the meteorological effect to the LUR modeling. One limitation of this study is that the models are not applicable to mountainous areas since the locations of samples were mainly distributed at altitude $<250 \mathrm{~m}$.

\section{Conclusions}

In this technical note, the efficacy of developing LUR models for $\mathrm{PM}_{2.5}$ and elemental composition with satellite-derived AOD was evaluated. The LOOCV $R^{2}$ for all PM measures were higher than 0.40 , except for $\mathrm{Al}, \mathrm{Cr}$, and $\mathrm{V}$, after including AOD and AOD_PER, indicating the critical improvements for model constructions. In HPS models, LOOCV $R^{2}$ of $\mathrm{Al}, \mathrm{Cr}$, and V significantly increased and were higher than 0.40 , demonstrating the improved utility of the models during hazy periods.

Supplementary Materials: The following are available online at https://www.mdpi.com/article/10 .3390/atmos12081018/s1, Table S1: Certified and measured values for PM measures using National Institute of Standards and Technology Standard Reference Material $2783(\mathrm{n}=3)$, Table S2: The definitions of predictor variables in constructions of LUR models, Table S3: Descriptive statistics of $\mathrm{PM}_{2.5}$ and elemental composition in annual value, HPS and LPS, Table S4: Summary of land use regression models of $\mathrm{PM}_{2.5}$ and elemental composition using annual averages (Method 1), Table S5: Summary of land use regression models of $\mathrm{PM}_{2.5}$ and elemental composition using annual averages (Method 2), Table S6: Summary of land use regression models of $\mathrm{PM}_{2.5}$ and elemental composition in high $\mathrm{PM}_{2.5}$ season (HPS) (Method 3), Table S7: Summary of land use regression models of $\mathrm{PM}_{2.5}$ and elemental composition in low $\mathrm{PM}_{2.5}$ season (LPS) (Method 3), Figure S1: Comparison of monthly $\mathrm{PM}_{2.5}$ concentration (black column) and ambient temperature (dotted line).

Funding: This study was funded by National Taiwan University (105R7812) and the 'Innovation and Policy Center for Population Health and Sustainable Environment (Population Health Research Center, PHRC), College of Public Health, National Taiwan University' from The Featured Areas Research Center Program within the framework of the Higher Education Sprout Project by the Ministry of Education of Taiwan (NTU-107L9003).

Institutional Review Board Statement: Not applicable.

Informed Consent Statement: Not applicable.

Data Availability Statement: The data availability and collection are described in Material and Methods and Table S2 of Supplementary Materials.

Acknowledgments: We thank Taiwan Environmental Protection Administration for providing $\mathrm{PM}_{2.5}$ filter samples.

Conflicts of Interest: The authors declare no conflict of interest.

\section{References}

1. Pope, C.A., III; Dockery, D.W. Health effects of fine particulate air pollution: Lines that connect. J. Air Waste Manag. Assoc. 2006, 56, 709-742. [CrossRef] [PubMed]

2. Kampa, M.; Castanas, E. Human health effects of air pollution. Environ. Pollut. 2008, 151, 362-367. [CrossRef] [PubMed]

3. Seagrave, J.; McDonald, J.D.; Bedrick, E.; Edgerton, E.S.; Gigliotti, A.P.; Jansen, J.J.; Ke, L.; Naeher, L.P.; Seilkop, S.K.; Zheng, M.; et al. Lung Toxicity of Ambient Particulate Matter from Southeastern U.S. Sites with Different Contributing Sources: Relationships between Composition and Effects. Environ. Health Perspect. 2006, 114, 1387-1393. [CrossRef]

4. Pedersen, M.; Stayner, L.; Slama, R.; Sørensen, M.; Figueras, F.; Nieuwenhuijsen, M.J.; Raaschou-Nielsen, O.; Dadvand, P. Ambient Air Pollution and Pregnancy-Induced Hypertensive Disorders. Hypertension 2014, 64, 494-500. [CrossRef] 
5. Kelly, F.J.; Fussell, J.C. Size, source and chemical composition as determinants of toxicity attributable to ambient particulate matter. Atmospheric Environ. 2012, 60, 504-526. [CrossRef]

6. Stanek, L.W.; Sacks, J.D.; Dutton, S.J.; Dubois, J.-J.B. Attributing health effects to apportioned components and sources of particulate matter: An evaluation of collective results. Atmospheric Environ. 2011, 45, 5655-5663. [CrossRef]

7. Thurston, G.D.; Burnett, R.T.; Turner, M.C.; Shi, Y.; Krewski, D.; Lall, R.; Ito, K.; Jerrett, M.; Gapstur, S.M.; Diver, W.R.; et al. Ischemic Heart Disease Mortality and Long-Term Exposure to Source-Related Components of U.S. Fine Particle Air Pollution. Environ. Health Perspect. 2016, 124, 785-794. [CrossRef] [PubMed]

8. Achilleos, S.; Kioumourtzoglou, M.-A.; Wu, C.-D.; Schwartz, J.D.; Koutrakis, P.; Papatheodorou, S.I. Acute effects of fine particulate matter constituents on mortality: A systematic review and meta-regression analysis. Environ. Int. 2017, 109, 89-100. [CrossRef]

9. Yang, J.; Zhou, M.; Li, M.; Yin, P.; Hu, J.; Zhang, C.; Wang, H.; Liu, Q.; Wang, B. Fine particulate matter constituents and cause-specific mortality in China: A nationwide modelling study. Environ. Int. 2020, 143, 105927. [CrossRef]

10. Hoek, G.; Beelen, R.; De Hoogh, K.; Vienneau, D.; Gulliver, J.; Fischer, P.; Briggs, D. A review of land-use regression models to assess spatial variation of outdoor air pollution. Atmospheric Environ. 2008, 42, 7561-7578. [CrossRef]

11. ESCAPE. ESCAPE Exposure Assessment Manual. Available online: http://www.escapeproject.eu/manuals/ESCAPE_Exposuremanualv9.pdf (accessed on 26 January 2019).

12. Eeftens, M.; Beelen, R.; De Hoogh, K.; Bellander, T.; Cesaroni, G.; Cirach, M.; Declercq, C.; Dèdelè, A.; Dons, E.; de Nazelle, A.; et al. Development of Land Use Regression Models for $\mathrm{PM}_{2.5}, \mathrm{PM}_{2.5}$ Absorbance, $\mathrm{PM}_{10}$ and $\mathrm{PM}_{\text {coarse }}$ in 20 European Study Areas; Results of the ESCAPE Project. Environ. Sci. Technol. 2012, 46, 11195-11205. [CrossRef]

13. Lee, J.-H.; Wu, C.-F.; Hoek, G.; de Hoogh, K.; Beelen, R.; Brunekreef, B.; Chan, C.-C. Land use regression models for estimating individual $\mathrm{NO}_{\mathrm{x}}$ and $\mathrm{NO}_{2}$ exposures in a metropolis with a high density of traffic roads and population. Sci. Total. Environ. 2014, 472, 1163-1171. [CrossRef]

14. Wu, C.-D.; Chen, Y.-C.; Pan, W.-C.; Zeng, Y.-T.; Chen, M.-J.; Guo, Y.L.; Lung, S.-C.C. Land-use regression with long-term satellite-based greenness index and culture-specific sources to model $\mathrm{PM}_{2.5}$ spatial-temporal variability. Environ. Pollut. 2017, 224, 148-157. [CrossRef]

15. Wu, C.-F.; Lin, H.-I.; Ho, C.-C.; Yang, T.-H.; Chen, C.-C.; Chan, C.-C. Modeling horizontal and vertical variation in intraurban exposure to $\mathrm{PM}_{2.5}$ concentrations and compositions. Environ. Res. 2014, 133, 96-102. [CrossRef] [PubMed]

16. de Hoogh, K.; Wang, M.; Adam, M.; Badaloni, C.; Beelen, R.; Birk, M.; Cesaroni, G.; Cirach, M.; Declercq, C.; Dèdelè, A.; et al. Development of Land Use Regression Models for Particle Composition in Twenty Study Areas in Europe. Environ. Sci. Technol. 2013, 47, 5778-5786. [CrossRef]

17. Hsu, C.-Y.; Wu, C.-D.; Hsiao, Y.-P.; Chen, Y.-C.; Chen, M.-J.; Lung, S.-C.C. Developing Land-Use Regression Models to Estimate $\mathrm{PM}_{2.5}$ - Bound Compound Concentrations. Remote Sens. 2018, 10, 1971. [CrossRef]

18. Ito, K.; Johnson, S.; Kheirbek, I.; Clougherty, J.; Pezeshki, G.; Ross, Z.; Eisl, H.; Matte, T.D. Intraurban Variation of Fine Particle Elemental Concentrations in New York City. Environ. Sci. Technol. 2016, 50, 7517-7526. [CrossRef] [PubMed]

19. Tunno, B.J.; Shmool, J.L.; Michanowicz, D.R.; Tripathy, S.; Chubb, L.; Kinnee, E.; Cambal, L.; Roper, C.; Clougherty, J.E. Spatial variation in diesel-related elemental and organic $\mathrm{PM}_{2.5}$ components during workweek hours across a downtown core. Sci. Total. Environ. 2016, 573, 27-38. [CrossRef]

20. Brokamp, C.; Jandarov, R.; Rao, M.; LeMasters, G.; Ryan, P. Exposure assessment models for elemental components of particulate matter in an urban environment: A comparison of regression and random forest approaches. Atmospheric Environ. 2017, 151, 1-11. [CrossRef] [PubMed]

21. Dirgawati, M.; Heyworth, J.; Wheeler, A.; McCaul, K.A.; Blake, D.; Boeyen, J.; Cope, M.; Yeap, B.B.; Nieuwenhuijsen, M.; Brunekreef, B.; et al. Development of Land Use Regression models for particulate matter and associated components in a low air pollutant concentration airshed. Atmospheric Environ. 2016, 144, 69-78. [CrossRef]

22. Chen, J.; De Hoogh, K.; Gulliver, J.; Hoffmann, B.; Hertel, O.; Ketzel, M.; Weinmayr, G.; Bauwelinck, M.; Van Donkelaar, A.; Hvidtfeldt, U.A.; et al. Development of Europe-Wide Models for Particle Elemental Composition Using Supervised Linear Regression and Random Forest. Environ. Sci. Technol. 2020, 54, 15698-15709. [CrossRef] [PubMed]

23. Tripathy, S.; Tunno, B.J.; Michanowicz, D.R.; Kinnee, E.; Shmool, J.L.; Gillooly, S.; Clougherty, J.E. Hybrid land use regression modeling for estimating spatio-temporal exposures to $\mathrm{PM}_{2.5}, \mathrm{BC}$, and metal components across a metropolitan area of complex terrain and industrial sources. Sci. Total. Environ. 2019, 673, 54-63. [CrossRef]

24. Huang, C.-S.; Lin, T.-H.; Hung, H.; Kuo, C.-P.; Ho, C.-C.; Guo, Y.-L.; Chen, K.-C.; Wu, C.-F. Incorporating satellite-derived data with annual and monthly land use regression models for estimating spatial distribution of air pollution. Environ. Model. Softw. 2019, 114, 181-187. [CrossRef]

25. QGIS Development Team. QGIS Geographic Information System. Available online: https:/ / qgis.osgeo.org (accessed on 16 April 2019).

26. Gugamsetty, B.; Wei, H.; Liu, C.-N.; Awasthi, A.; Hsu, S.-C.; Tsai, C.-J.; Roam, G.-D.; Wu, Y.-C.; Chen, C.-F. Source Characterization and Apportionment of $\mathrm{PM}_{10}, \mathrm{PM}_{2.5}$ and $\mathrm{PM}_{0.1}$ by Using Positive Matrix Factorization. Aerosol Air Qual. Res. 2012, 12, $476-491$. [CrossRef]

27. Liu, W.; Wang, Y.; Russell, A.; Edgerton, E.S. Atmospheric aerosol over two urban-rural pairs in the southeastern United States: Chemical composition and possible sources. Atmospheric Environ. 2005, 39, 4453-4470. [CrossRef] 
28. Vallius, M.; Lanki, T.; Tiittanen, P.; Koistinen, K.; Ruuskanen, J.; Pekkanen, J.; Vallius, M.; Lanki, T.; Tiittanen, P.; Koistinen, K.; et al. Source apportionment of urban ambient $\mathrm{PM}_{2.5}$ in two successive measurement campaigns in Helsinki, Finland. Atmospheric Environ. 2003, 37, 615-623. [CrossRef]

29. Sternbeck, J.; Sjödin, Å.; Andréasson, K. Metal emissions from road traffic and the influence of resuspension-Results from two tunnel studies. Atmospheric Environ. 2002, 36, 4735-4744. [CrossRef]

30. Hjortenkrans, D.; Bergbäck, B.; Häggerud, A. New Metal Emission Patterns in Road Traffic Environments. Environ. Monit. Assess. 2006, 117, 85-98. [CrossRef]

31. Birmili, W.; Allen, A.G.; Bary, F.; Harrison, R.M. Trace Metal Concentrations and Water Solubility in Size-Fractionated Atmospheric Particles and Influence of Road Traffic. Environ. Sci. Technol. 2006, 40, 1144-1153. [CrossRef]

32. Heo, J.-B.; Hopke, P.; Yi, S.-M. Source apportionment of $\mathrm{PM}_{2.5}$ in Seoul, Korea. Atmospheric Chem. Phys. Discuss. 2009,9 , $4957-4971$. [CrossRef]

33. Han, J.S.; Moon, K.J.; Lee, S.J.; Kim, Y.J.; Ryu, S.Y.; Cliff, S.S.; Yi, S.M. Size-resolved source apportionment of ambient particles by positive matrix factorization at Gosan background site in East Asia. Atmospheric Chem. Phys. Discuss. 2006, 6, 211-223. [CrossRef]

34. Lee, J.H.; Hopke, P.K. Apportioning sources of $\mathrm{PM}_{2.5}$ in St. Louis, MO using speciation trends network data. Atmospheric Environ. 2006, 40, 360-377. [CrossRef]

35. Du, W.; Hong, Y.-W.; Xiao, H.; Zhang, Y.; Chen, Y.; Xu, L.; Chen, J.; Deng, J. Chemical Characterization and Source Apportionment of $\mathrm{PM}_{2.5}$ during Spring and Winter in the Yangtze River Delta, China. Aerosol Air Qual. Res. 2017, 17, 2165-2180. [CrossRef]

36. Dimitriou, K.; Remoundaki, E.; Mantas, E.; Kassomenos, P. Spatial distribution of source areas of $\mathrm{PM}_{2.5}$ by Concentration Weighted Trajectory (CWT) model applied in $\mathrm{PM}_{2.5}$ concentration and composition data. Atmospheric Environ. 2015, 116, 138-145. [CrossRef]

37. Liu, B.; Song, N.; Dai, Q.; Mei, R.; Sui, B.; Bi, X.; Feng, Y. Chemical composition and source apportionment of ambient PM 2.5 during the non-heating period in Taian, China. Atmospheric Res. 2016, 170, 23-33. [CrossRef]

38. Ho, C.-C.; Chan, C.-C.; Cho, C.-W.; Lin, H.-I.; Lee, J.-H.; Wu, C.-F. Land use regression modeling with vertical distribution measurements for fine particulate matter and elements in an urban area. Atmospheric Environ. 2015, 104, 256-263. [CrossRef]

39. Yu, T.-Y.; Chang, I.-C. Spatiotemporal Features of Severe Air Pollution in Northern Taiwan (8 pp). Environ. Sci. Pollut. Res. 2006, 13, 268-275. [CrossRef]

40. Adam, M.; Schikowski, T.; Carsin, A.E.; Cai, Y.; Jacquemin, B.; Sanchez, M.; Vierkötter, A.; Marcon, A.; Keidel, D.; Sugiri, D.; et al. Adult lung function and long-term air pollution exposure. ESCAPE: A multicentre cohort study and meta-analysis. Eur. Respir. J. 2014, 45, 38-50. [CrossRef]

41. Chen, S.-Y.; Wu, C.-F.; Lee, J.-H.; Hoffmann, B.; Peters, A.; Brunekreef, B.; Chu, D.-C.; Chan, C.-C. Associations between Long-Term Air Pollutant Exposures and Blood Pressure in Elderly Residents of Taipei City: A Cross-Sectional Study. Environ. Health Perspect. 2015, 123, 779-784. [CrossRef]

42. Morgenstern, V.; Zutavern, A.; Cyrys, J.; Brockow, I.; Gehring, U.; Koletzko, S.; Bauer, C.P.; Reinhardt, D.; Wichmann, H.-E.; Heinrich, J. Respiratory health and individual estimated exposure to traffic-related air pollutants in a cohort of young children. Occup. Environ. Med. 2006, 64, 8-16. [CrossRef]

43. Wolf, K.; Stafoggia, M.; Cesaroni, G.; Andersen, Z.J.; Beelen, R.; Galassi, C.; Hennig, F.; Migliore, E.; Penell, J.; Ricceri, F.; et al. Long-term Exposure to Particulate Matter Constituents and the Incidence of Coronary Events in 11 European Cohorts. Epidemiology 2015, 26, 565-574. [CrossRef] [PubMed] 